\title{
CYPHODERRIS MONSTROSA.
}

BY SAMUEL H. SCUDDER, CAMBRIDGE, MASS.

From time to time during the last two or three years, Dr. James Fletcher has sent me specimens of a curious Locustarian taken at Banff, Alberta, by Mr. N. B. Sanson, curator of the Government museum in the National Park at that place. The specimens were all wingless and apparently immature females, but quite unlike anything known from that region. A study of their structure showed that they belonged to the Stenopelmatini and were most nearly allied to the genus Cyphoderris. Now, Cyphoderris, though described by Uhler thirty.six years ago, is a rare creature and was on record from only two localities, Oregon and Wind River, Wyo., and only males had hitherto been taken. The probability that these immature and wingless females belonged with the winged males appeared to me, however, so great that in my recent catalogue of North American Orthoptera I recorded the species given in the title above as found in Alberta.

Nevertheless, I had misgivings and asked Dr. Fletcher to obtain mature specimens to make sure. By his urgency, Mr. Sanson has forwarded separately this last autumn two mature females aliv'e, the first of which Mr. Fletcher sent to me. These were in no respect different from the immature specimens except in size and in slight traces of wing-pads beneath the pronotal shield; while in the appearance of the pronotum they differed so greatly from the male of Cyphoderris that I was as much at a loss as ever; for the male Cyphoderris has the posterior half of the pronotum so hunched and enlarged as to be almost a half broader posteriorly than anteriorly; this is to give room for the coarse and bellied tegmina, which it overhangs, which are considerably longer than the pronotum, and nearly the whole of whose dorsal surface is made up of a coarse stridulating organ. But the females sent had a pronotum of nearly uniform diameter and practically no wings. Only by securing a male from the same region or females from Oregon or Wyoming could the question really be decided whether these represented closely-related genera or the same or nearly-allied species. The matter has just been definitely settled by the receipt of a male from Banff, kindly sent by $\mathrm{Mr}$. Sanson from his collection, which cannot be separated from the Oregon types in my possession. Mr. Sanson responded generously to the 
demands upon him; he obtained his specimens under logs and stones where he had placed old bones as a bait. They appear to be scarce, and he has so far secured but one male.

The occurrence of such a form so far north is of particular interest, for Cyphoderris belongs to a group of Anostostomata (a subdivision of Stenopelmatini) which is purely American, but mainly tropical, its northernmost allies being found in Mexico. Moreover, the Old World species and genera of Anostostomata are from the southern hemisphere exclusively.

Both Mr. Fletcher and I kept our females alive for nearly a month, feeding them chiefly on apples, of which they partook rather sparingly. They were very sluggish, as seemed fit for such heavy-bodied creatures, and could scarcely jump at all, not above half an inch at a time, and were more active by night than by day. Whether eggs are laid in the autumn or spring is uncertain; the former would seem probable from their dying in captivity before November, the latter from the fact that when captured in September the thermometer stood at $19^{\circ} \mathrm{F}$. I gave my specimen no water, but Mr. Fletcher gave his some from a brush, which she drank, but, he writes me, "if I push the brush too assiduously she turns over on her back and bites and kicks savagely and then lies perfectly still." After death the abdomen contracts greatly.

Taking advantage of possessing a living specimen, I took notes of the colouring, etc., from which the following description of the female is taken :

Head above the antennæ bronze black, longitudinally marked with pallid luteous; genæ and face below the antennae pale lilac, excepting the clypeus and labrum, which are pale lemon yellow, the whole marked with blackish; palpi pallid, feebly infuscated, especially the maxillary pair, in stripes and apical marginings, the extreme apex of apical joint pallid; basal joint of antennæ pallid, with broad basal and narrow subapical fuscous annuli, the remaining joints bronze black; eyes castaneous.

Pronotum subcylindrical, subequal, very feebly constricted just in advance of the middle, dull luteous with a nacreous sheen, the posterior edge and lower margins of the lateral lobes flavous or flavescent, the whole heavily and massively marked, especially in the constricted region, with very dark glistening bronze green, the whole surface, whether dark 
or light, sprinkled very sparsely and very inconspicuously with iuteous dots. Sternal parts of thorax luteous, more or less infuscated. Tegmina reduced to minute membranous testaceous pads, concealed beneath the pronotum. Coxæ and trochanters blackish fuscous; femora luteotestaceous, the whole apex and a broad longitudinal median band on the outer side subpiceous ; tibiæ pallid luteous, with a piceous stripe following the upper lateral spinigerous margins, heavier in basal than in apical half; the fore pair with one spine above on inner margin, besides an apical one, none on the outer margin, below with two or three spines on each side, besides the apical one; the middle pair with no spines below, two or three on either side above, besides the apical one; and the hind pair with no spines below and six or seven on either side above, besides the apical one; the spines pallid or luteous tipped with black, excepting the apical spines, which are almost wholly fuscous; tarsi very pale red beneath, pallid above, edged apically with fuscous.

Abdomen very plump, deeper than broad, having above the same colours as the pronotum, the luteous nacre forming the base, and the bronze green, somewhat embrowned, confined to the apical margins of the segments in an irregular edging; sides of abdomen between the dorsal and ventral scutes pale brown, sparsely sprinkled with pallid dots, the spiracles glistening bronze.

Length of body, 2 I mm.; pronotum, $8 \mathrm{~mm}$.; breadth of same, $7 \mathrm{~mm}$.; length of antennæ, $25 \mathrm{~mm}$.; hind femora, I I mm.; hind tibiæ, $10.5 \mathrm{~mm}$.; hind tarsi, $7 \mathrm{~mm}$.

[Mr. Sanson states that these insects are by no means common at Banff. The first specimen he acquired was found in the basement of the Canadian Pacific Hotel, by Miss Adams, of Winnipeg; Mr. W. C. McCalla, of St. Catharines, Ont., took two immature specimens among the fir boughs used as a bed in his camp. One specimen was given to Dr. White, of Banff, by Mr. George Paris, of the same place. Mr. Sanson caught two mature females, one by placing some biscuits and brown sugar under a sheet of botanical drying felt near one of the summer residences off Tunnel Mountain Rd., near the place where the perfect male referred to above was taken; the second was found under a log where a bone had been placed as a bait; and the last specimen found was brought to him by a member of a camping party, who had it for a few days and brought it in alive. In all, seven specimens have been secured.-ED.] 


\section{$2 \mathrm{BHL}$ Biodiversity Heritage Library}

Scudder, Samuel Hubbard. 1901. "Cyphoderris Monstrosa." The Canadian entomologist 33, 17-19. https://doi.org/10.4039/Ent3317-1.

View This Item Online: https://www.biodiversitylibrary.org/item/22101

DOI: https://doi.org/10.4039/Ent3317-1

Permalink: https://www.biodiversitylibrary.org/partpdf/17677

\section{Holding Institution}

MBLWHOI Library

\section{Sponsored by}

MBLWHOI Library

\section{Copyright \& Reuse}

Copyright Status: NOT_IN_COPYRIGHT

This document was created from content at the Biodiversity Heritage Library, the world's largest open access digital library for biodiversity literature and archives. Visit BHL at https://www.biodiversitylibrary.org. 